\title{
Functional feeding groups of Brazilian Ephemeroptera nymphs : ultrastructure of mouthparts
}

\author{
D.F. Baptista1*, D.F. Buss¹, L.G. Dias¹, J.L. Nessimian², E.R. Da Silva ${ }^{3}$, A.H.A. De Moraes Neto ${ }^{4}$, S.N. de \\ Carvalho $^{4}$, M.A. De Oliveira ${ }^{5}$, L.R. Andrade 6
}

\footnotetext{
${ }^{1}$ Laboratório de Avaliação e Promoção da Saúde Ambiental, Departamento de Biologia, IOC FIOCRUZ, Av. Brasil, 4.365, Manguinhos, RJ, Brazil, CEP 21045-900.

2 Laboratório de Entomologia, Departamento de Zoologia, CCS - UFRJ, Ilha do Fundão, Rio de Janeiro, Brazil, CEP 21944-970.

3 Laboratório de Insetos Aquáticos, Departamento de Ciências Naturais, CCBS - UNIRIO, Av. Pasteur, 458, $4^{\circ}$ andar, Urca, Rio de Janeiro, Brazil, CEP 22290-240.

${ }^{4}$ Núcleo de Biologia e Controle de Endo e Ectoparasitas de Interesse Médico e Veterinário, Departamento de Biologia, IOC FIOCRUZ and Lab. de Biologia Celular e Tecidual, Centro de Biociências e Biotecnologia, CBB - UENF, Brazil, CEP 28013-602.

5 Instituto de Pesquisa e Desenvolvimento, UNIVAP.

${ }^{6}$ Laboratório de Biomineralização, Departamento de Histologia e Embriologia, Instituto de Ciências Biomédicas, CCS - Universidade Federal do Rio de Janeiro, Ilha do Fundão, Rio de Janeiro, RJ, Brazil, CEP 20941-590.
}

\begin{abstract}
In order to assign 18 mayfly taxa found in streams in the Macaé River basin into Functional Feeding Groups, the anatomy of their feeding apparatus was examined through scanning electron microscopy. Also, habitat preference and field observations of feeding behaviour were made to assure FFG assignment. Ephemeropteran taxa were classified into five FFGs: Passive Filterers - Hylister plaumanni; Active Filterer Lachlania boanovae and Campylocia sp.; Brushers - Askola froehlichi, Farrodes carioca, Hagenulopsis spp., Massartela brieni, Miroculis froehlich, Miroculis sp., and Thraulodes spp; Grazers - Cloeodes spp., Americabaetis spp., Camelobaetidius spp.and Baetodes spp.; Scrapers Leptohyphes pereirae, Leptohyphes spp., Tricorythodes spp. and Tricorythopsis spp. Species of the three best represented mayfly families in south-east Brazil were assigned to different FFGs (Leptophlebiidae - Brushers; Baetidae - Grazers and Leptohyphidae - Scrapers), with one exception, Hylister plaumanni (Leptophlebiidae; Active filterers). This information is useful to understand the role of mayflies in stream ecosystems, and to help the development of ecological theories for tropical streams.
\end{abstract}

Keywords : Ephemeroptera, FFG, neotropical streams, scanning electron microscopy, ultrastructure of mouthparts.

\section{Introduction}

In freshwater ecology, particularly in studies of running waters, the consideration of feeding relationships of benthic macroinvertebrates has been crucial to conceptualizing community dynamics and predicting ecological relationships (Vannote et al. 1980). Cummins $(1973,1974)$ concluded that mouthpart morphology was a good reflection of feeding mechanism, as animals can only be opportunistic within the limitation of their feeding morphology and the behavior that drives it.

\footnotetext{
* Corresponding author :

E-mail: darcilio@ioc.fiocruz.br
}

McShaffrey \& McCafferty $(1986,1988)$ have demonstrated the advantages of using combined methods to assign macroinvertebrates to Functional Feeding Group (FFG) categories, including mouthpart morphology and behaviour. According to Arens (1989), insect mouthparts morphologic pre-adaptations allow only some behavioural arrangements for the obtainment of specific feeding resources. In insects, basal parts of the labium (post and prementum) are always fused medially and its distal appendages have low mobility (glossae and paraglossae). Generally, only the labial palps have enough mobility to manipulate food, and the more robust distal parts of the maxillae (laciniae and galeae) are theoretically suited for scraping hard surfaces. Also, mandibles are able to move freely, being hard enough to scrap and/or triturate food.

Article available at http://www.limnology-journal.org or http://dx.doi.org/10.1051/limn/2006013 
Some studies on mayflies have combined observation and morphological analyses (Brown 1961, Froehlich 1964, Palmer et al. 1993). Based on morphological ancestral adaptations, Ephemeroptera nymphs are more often assigned to two basic FFGs, filterers and collectors (Arens 1989, Arens 1990, Elpers \& Tomka 1994), although some are predators and only a few are shredders (Edmunds et al. 1976, Merritt \& Cummins 1996).

Since most studies dealing with aquatic insect FFGs were conducted in temperate ecosystems, with only a few studies conducted in other regions (Palmer et al. 1993, Bello \& Cabreras 2001, Cummins et al. 2005), the aim of this study was to analyze the anatomy of the feeding apparatus of 18 mayfly taxa found in streams in south-east Brazil through scanning electron microscopy in order to assign these taxa to FFGs. Also, we described habitat preference and in-field observations of feeding behaviour to aid in the assignment of species to FFGs.

\section{Methods}

\section{Sampling and FFG classification}

Mayfly nymphs were sampled in Macaé River basin, Rio de Janeiro State, Brazil, a $6^{\text {th }}$ order river, located in the Serra do Mar mountains. Sites sampled were in $1^{\text {st }}$, $2^{\text {nd }}, 4^{\text {th }}, 5^{\text {th }}$, and $6^{\text {th }}$ order stream reaches. Sampling sites were at altitudes between 60 and $1100 \mathrm{~m}$ a.s.l. Two distinct macroinvertebrate assemblages were found in this basin: one from first to fourth order stream reaches (upper reaches), and other comprising fifth and sixth order stream reaches (lower reaches) (Baptista et al. 2001). Specimens were collected from four substrate types (fine sediment and litter in pool areas; stones and litter in riffle areas) using a Surber sampler $\left(900 \mathrm{~cm}^{2}\right.$, mesh size $\left.125 \mu \mathrm{m}\right)$, and preserved in $80 \%$ ethanol for further examination of mouthparts.

The basic system for FFG assignment was the classification scheme of Cummins (1973, 1974), based on the resource partitioning. In this study, we also considered the classification scheme described in Palmer et al. (1993), based in part on McShaffrey \& McCafferty (1988), because it allows the inclusion of additional ecological information on how macroinvertebrates acquire these resources. In this respect, we included the Grazer FFG, as follows:

(a) Filterers

(i) Passive - feed on seston, which is moved by a current, using body parts (ii) Active - resuspend deposits which are filtered using body parts

(b) Collectors

(i) Gatherers - use structures other than setae to remove lightly attached or loosely deposited organic material

(ii) Brushers - use setae to remove lightly attached or loosely deposited organic material

(iii) Scrapers - have structural adaptations which allow to feed from tightly accreted material

(iv) Grazers - use mouthparts to feed on algae, by reaping off parts of living material

\section{Ultrastructure of mouthparts}

For scanning electron microscopy, mouthparts were fixed in $70 \%$ ethanol, washed with cacodylate buffer, post fixed in $1 \% \mathrm{OsO}_{4}$ in $0.1 \mathrm{M}$ cacodylate buffer containing $0.8 \%$ potassium ferrocyanide and $5 \mathrm{mM}$ $\mathrm{CaCl}_{2}$, washed with cacodylate buffer, dehydrated in a graded ethanol series, critical point dried, sputter coated with gold, and examined in a Jeol JSM 5310 scanning electron microscope operating at $15 \mathrm{kV}$.

\section{Results}

Generally, labia and maxilla provided the most useful information on feeding strategy used by Ephemeroptera nymphs. Taxa were assigned to five FFGs: Passive Filterers, Active Filterers, Brushers, Grazers or Scrapers.

The species Askola froehlichi (Peter 1969), Farrodes carioca (Dominguez et al. 1996), Hagenulopsis sp., Massartela brieni (Lestage 1924), Miroculis froehlichi (Savage \& Peter 1983), Miroculis sp., and Thraulodes spp (Leptophlebiidae) were assigned to the Brusher FFG category. In these species, the distal part of the maxilla ends in a tuft of brush-shaped setae (Figs 1a, b, c). The labrum is covered by few short setae, except the distal part where a fringe of bipectinate setae is present (Fig. 1d; Table 1). Such features are ideal for brushing lightly attached or loosely deposited organic material. A. froehlichi was associated exclusively with slow-flowing depositional areas in the upper reaches. $M$. froehlichi was restricted to the lower reaches, while Miroculis sp. occurred only in the upper reaches. F. carioca, Hagenulopsis sp., and Thraulodes spp. occurred all along the longitudinal gradient, the latter restricted to high-current areas.

The species Hylister plaumanni (Dominguez \& Flower 1989) was an exception among the leptophlebiids. 
Table 1. Ultrastructural features of the Labial paraglossa, Labial palps, Maxilla, Maxillary palps, and other morphological features of 18 Macaé River mayfly nymphs and their assignment to Functional Feeding Groups (FFG), and FFG classification according to Merritt \& Cummins (1996) (FFG\#).

\begin{tabular}{|c|c|c|c|c|c|c|c|}
\hline TAXA & FFG & FFG\# & Labial paraglossa & Labial palps & Maxilla & Maxillary palps & Other features \\
\hline $\begin{array}{l}\text { Hylister plaumanni } \\
\text { (Leptophlebiidae) }\end{array}$ & $\begin{array}{l}\text { Passive } \\
\text { Filterer }\end{array}$ & $\begin{array}{l}\text { Collector } \\
\text {-filterer }\end{array}$ & $\begin{array}{l}\text { Dense fringe of } \\
\text { bipectinate setae }(200- \\
500 \mu \mathrm{m})\end{array}$ & $\begin{array}{l}\text { Long filtering setae } \\
(\geq 800 \mu \mathrm{m})\end{array}$ & $\begin{array}{l}\text { Long filtering setae } \\
(\geq 800 \mu \mathrm{m})\end{array}$ & $\begin{array}{l}\text { Long filtering setae } \\
(\geq 800 \mu \mathrm{m})\end{array}$ & \\
\hline $\begin{array}{l}\text { Campylocia sp. } \\
\text { (Euthyplociidae) }\end{array}$ & $\begin{array}{l}\text { Active } \\
\text { Filterer }\end{array}$ & $\begin{array}{l}\text { Collector } \\
\text {-filterer }\end{array}$ & $\begin{array}{l}\text { Bipectinate setae } \\
(200-400 \mu \mathrm{m})\end{array}$ & $\begin{array}{l}\text { Sparse long filtering } \\
\text { setae }(\geq 800 \mu \mathrm{m})\end{array}$ & $\begin{array}{l}\text { Long filtering setae } \\
(\geq 800 \mu \mathrm{m})\end{array}$ & $\begin{array}{l}\text { Apical tuft of long } \\
\text { filtering setae }(\geq 800 \mu \mathrm{m})\end{array}$ & $\begin{array}{l}\text { Long mandibular tusks } \\
\text { with setae }(\geq 800 \mu \mathrm{m})\end{array}$ \\
\hline $\begin{array}{l}\text { Lachlania boanovae } \\
\text { (Oligoneuriidae) }\end{array}$ & $\begin{array}{l}\text { Active } \\
\text { Filterer }\end{array}$ & $\begin{array}{l}\text { Collector } \\
\text {-filterer }\end{array}$ & $\begin{array}{l}\text { Bipectinate setae }(20- \\
200 \mu \mathrm{m}) \text { with short } \\
\text { microtrichia }(<5 \mu \mathrm{m})\end{array}$ & $\begin{array}{l}\text { Fringe of setae }(20- \\
200 \mu \mathrm{m})\end{array}$ & $\begin{array}{l}\text { Fringe of setae }(20- \\
200 \mu \mathrm{m})\end{array}$ & $\begin{array}{l}\text { Fringe of setae }(20- \\
200 \mu \mathrm{m})\end{array}$ & $\begin{array}{l}\text { Forelegs with long setae } \\
\text { without microtrichia }\end{array}$ \\
\hline $\begin{array}{l}\text { Askola froehlichi, } \\
\text { Farrodes carioca, } \\
\text { Hagenulopsis sp., } \\
\text { Massartela brieni, } \\
\text { Miroculis froehlichi, } \\
\text { Miroculis sp., } \\
\text { Thraulodes spp. } \\
\text { (Leptophlebiidae) }\end{array}$ & Brusher & $\begin{array}{l}\text { Collector } \\
\text {-gatherer }\end{array}$ & $\begin{array}{l}\text { Dense fringe of } \\
\text { bipectinate setae }(20- \\
200 \mu \mathrm{m})\end{array}$ & $\begin{array}{l}\text { Apical tuft of setae } \\
(20-200 \mu \mathrm{m})\end{array}$ & $\begin{array}{l}\text { Dense tuft of setae } \\
(200-300 \mu \mathrm{m})\end{array}$ & $\begin{array}{l}\text { Apical tuft of setae } \\
(200-300 \mu \mathrm{m})\end{array}$ & \\
\hline $\begin{array}{l}\text { Baetodes sp., } \\
\text { Americabaetis spp., } \\
\text { Camelobaetidius } \\
\text { spp. Cloeodes spp. } \\
\text { (Baetidae) }\end{array}$ & Grazer & Scraper & $\begin{array}{l}\text { Long paraglossae with } \\
\text { bipectinate setae } \\
(<50 \mu \mathrm{m})\end{array}$ & $\begin{array}{l}\text { Few bipectinate setae } \\
(<50 \mu \mathrm{m})\end{array}$ & $\begin{array}{l}\text { Few bipectinate setae } \\
(<50 \mu \mathrm{m})\end{array}$ & Few short setae & $\begin{array}{l}\text { Americabaetis spp.: labial } \\
\text { palp segments } 2 \text { with a } \\
\text { moderate, distomedially } \\
\text { acute process }\end{array}$ \\
\hline $\begin{array}{l}\text { Leptohyphes } \\
\text { pereirae, } \\
\text { Leptohyphes spp., } \\
\text { Tricorythodes sp., } \\
\text { Tricorythopsis sp. } \\
\text { (Leptohyphidae) }\end{array}$ & Scraper & Scraper & $\begin{array}{l}\text { Sparse setae (20- } \\
200 \mu \mathrm{m}) \text { without } \\
\text { microtrichia }\end{array}$ & $\begin{array}{l}\text { Reduced palps with } \\
\text { few setae }\end{array}$ & $\begin{array}{l}\text { Robust comb-like } \\
\text { denticles, with } \\
\text { bipectinate setae tuft }\end{array}$ & $\begin{array}{l}\text { Reduced palps with few } \\
\text { setae }\end{array}$ & $\begin{array}{l}\text { Mandibles: distal part with } \\
\text { two chitinous wedge- } \\
\text { shaped teeth; and molar } \\
\text { part covered by robust } \\
\text { spiculae }\end{array}$ \\
\hline
\end{tabular}

It was assigned to the Passive Filterer FFG. The species have reduced glossa and paraglossa, and have long fringes of setae, designed to filter, with the labial palps and maxilla (Figs 2a, b, c; Table 1), suspended organic material carried by water current, and the most prominent structures used for filtering were the maxillary palps (Fig. 2d). In this study, H. plaumanni nymphs occurred exclusively in riffle biotopes, associated to litter substrates, in the lower reaches of the Macaé River.

In the species Lachlania boanovae (da Silva 1992) (Oligoneuriidae), the maxillae and labium are covered by dense fringes of setae, the labrum is large, dorsoventrally flattened and projected forward (Fig. 3a), long setae of fore leg (Fig. 3b). The species Campylocia sp. (Euthyplociidae), has maxillary palps with dense fringes (Fig. 3c) of bipectinate setae Fig. 3d). This species has long mandibular tusks covered with setae and forelegs with a dense fringe of setae (Fig. 3e). Based on the morphology of mouthparts and legs, these species could be assigned to the Passive Filterer FFG category. However, they were classified as Active Filterers because leg setae are without microtrichia, therefore not structurally adapted for passive filtering (according to Palmer et al. 1993). By way of corroborating this FFG assignment, they were associated with areas of low water current (Campylocia sp. in the upper reaches and L. boanovae in the lower stream reaches), and behavioural observations revealed that specimens used the internal margins of the anterior tibia (and femur in L. boanovae), which are covered with long setae (Fig. 3f), to resuspend organic particles (Campylocia sp. also uses its mandible tusks with this purpose; Table 1). In-field observations revealed that Campylocia sp. also used forelegs for cleaning mouthparts and/or sweeping organic particles to the pre-oral cavity.

Based solely on the ultrastructure of mouthparts, the species Americabaetis spp., Baetodes spp., Camelobaetidius spp., and Cloeodes spp. (Baetidae) would be classified as Collector-gatherers. However, they were classified as Grazers. They have complex mouth apparatus, with labial palps and articulated maxillary palps specialized to manipulate detritus. The paraglossae and glossae have few short setae (Figs 4a, b, c, d). On the tip of maxilla, there is a crown of chitinous teeth (Fig. 4b). The tip of the maxillae are covered by fringed curved bipectinate setae (Fig. 4e). These species probably use the long paraglossae to remove deposited particles, while labial and maxillary palps manipulate detritus. These genera were found in all biotopes, but occurred mainly on stony substrates. The design of their tarsal claws may be an adaptation to live under hydraulic stress and, in some species (like genus $\mathrm{Ca}$ melobaetidius), tarsal claws could be used for scraping (Fig. 4f). 


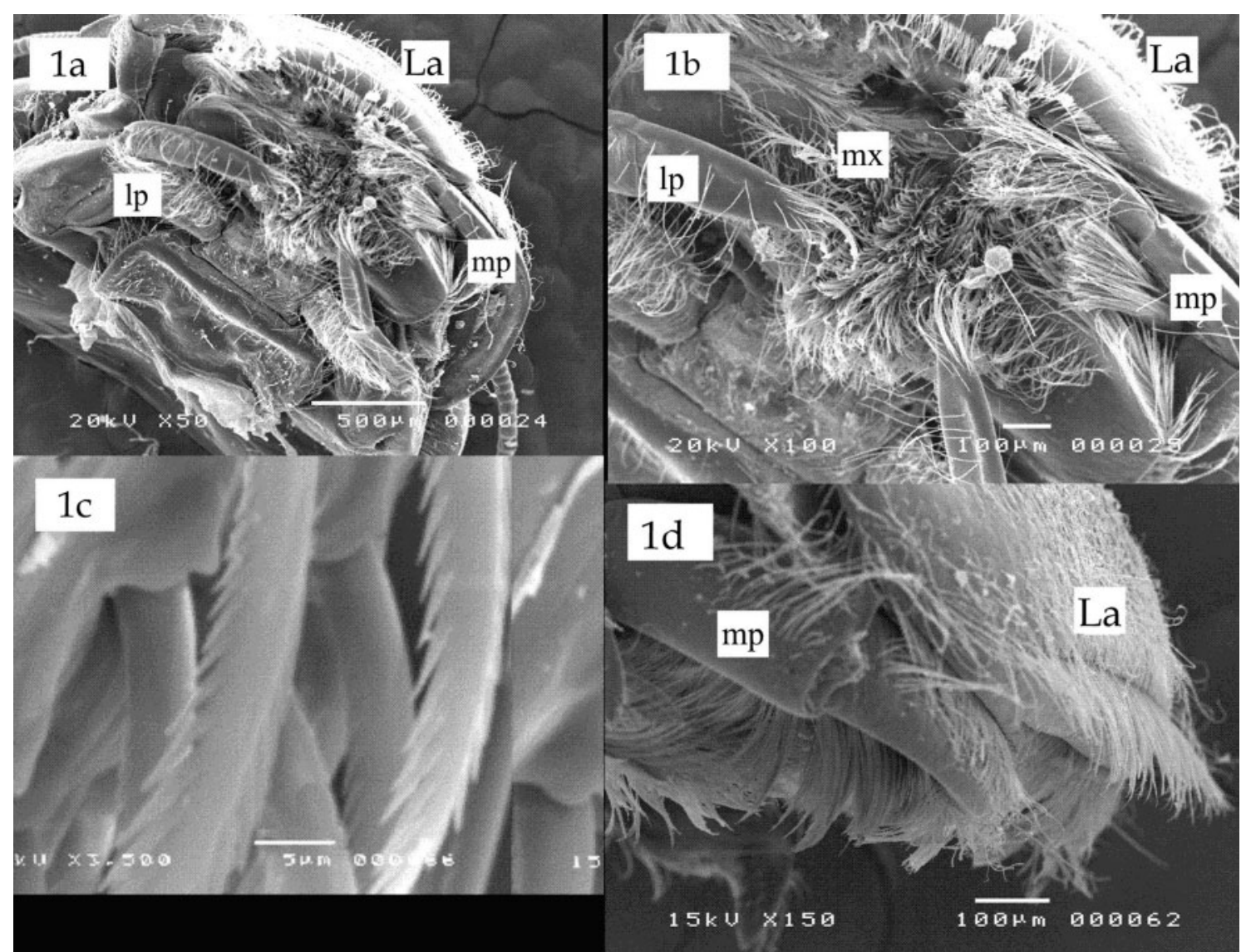

Fig. 1. Ultrastructure of mouthparts of Massartela brieni and Thraulodes sp. (Leptophlebiidae) assigned to the Brusher FFG. (a) Ventral view of mouthparts of M. brieni. La, Labrum; lp, Labial palp; mp, Maxillary palp. Scale bar $500 \mu \mathrm{m}$. (b) Closer ventral view of M. brieni. La, Labrum; lp, Labial palp; mp, Maxillary palp; mx, Maxillae. Scale bar $100 \mu \mathrm{m}$. (c) Maxillary setae of Thraulodes sp. Scale bar $5 \mu \mathrm{m}$. (d) Lateral view of mouthparts of Thraulodes sp. La, Labrum; mp, Maxillary palp. Scale bar $100 \mu \mathrm{m}$.

The species Leptohyphes pereirae (Pereira 1993), Leptohyphes spp., Tricorythodes sp. and Tricorythopsis $\mathrm{sp}$. were classified as Scrapers. On all mouth structures there are few small setae, clearly not suited for brushing or filtering activities (Figs 5a, b). In the distal part of the mandibles, there are two chitinous wedgeshaped teeth and the molar part is covered by robust spiculae, characterizing structures specialized for scraping periphyton (Figs 5c, d). These species were found predominantly in stream reaches with little canopy coverage ( $4^{\text {th }}$ and higher stream orders in stony and litter in riffle substrates).

\section{Discussion}

In this study, species of the family Leptophlebiidae were assigned to the Brusher FFG (Collector-gatherer
FFG, according to the Merritt \& Cummins (1996) classification scheme), with one exception, Hylister plaumanni. According to Polegatto \& Froehlich (2001), Farrodes sp. and other brusher leptophlebiids use the brushes of setae on the distal border of the maxillae to obtain food. The maxillary palps remove food particles from the brushes taking them towards the mandibles and hypopharynx, while the labrum and labium assist in retaining food. The labial palps are important in producing a water current towards the prebuccal cavity. In our study, all brusher leptophlebiid species had similar feeding apparatus to that of Farrodes sp. However, since these species had a broad occurrence in all substrates and along the longitudinal gradient, we speculate that the complex structure and function of mouthparts may allow brushing, filtering and gathering feeding cycles. McShaffrey (1988) ob- 


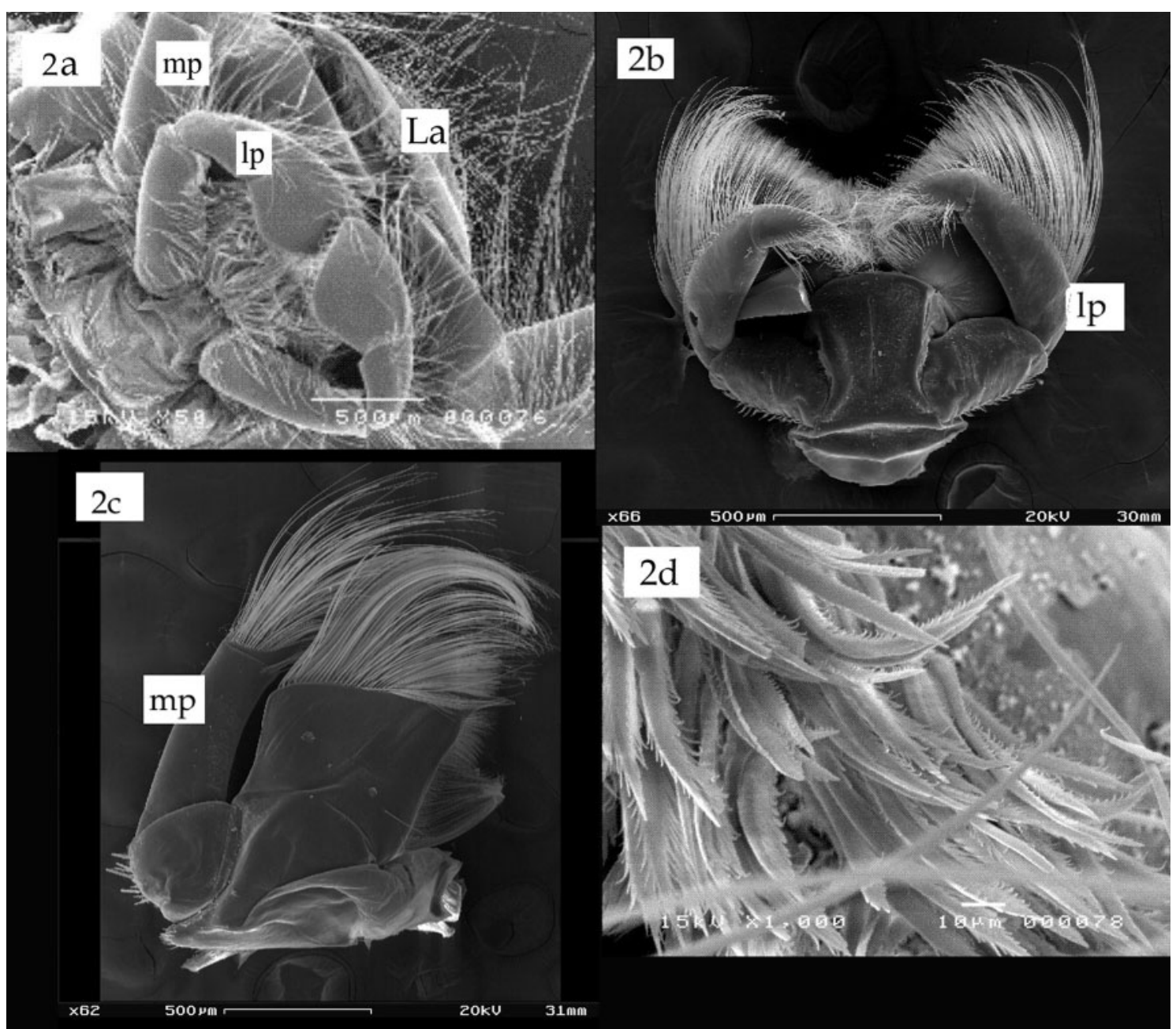

Fig. 2. Ultrastructure of mouthparts of Hylister plaumanni (Leptophlebiidae) assigned to the Passive Filterer FFG. (a) Ventral view of mouthparts. La, Labrum; mp, Maxillary palp; lp, Labial palps. Scale bar $500 \mu$ m. (b) Detail of labium. lp, labial palp. Scale bar $500 \mu$ m. (c) Detail of Maxilla. mp, Maxillary palp. (d) Apical setae of maxillary palps. Scale bar $10 \mu \mathrm{m}$.

served that two species of Heptageniidae and one species of Ephemerellidae used multiple feeding cycles, but assigned them to one FFG based on their predominant activity. Based on the morphological structure of their mouthparts, these leptophlebiid species were then classified as Brushers.

Morphology of the mouthparts of $H$. plaumanni indicates that it may feed on fine detritus in a different way from other leptophlebiid species. This species belong to the generic complex Hermanella (sensu Dominguez \& Flowers 1989), a distinct group in the subfamily Atalophlebiinae (Ephemeroptera: Leptophle- biidae). The six genera of this generic complex (Hermanella, Hylister, Leentvaria, Needhamella, Traverella and Hydrosmilodon) have a wide labrum and long fringes of setae on the labrum, maxillae and labium. The occurrence of $H$. plaumanni in litter in riffle areas, in the lower reaches of the Macaé River ( $5^{\text {th }}$ order stream, $655 \mathrm{~m}$ a.s.1.), where there was higher availability of suspended organic particles (Baptista et al. 2001) corroborates its assignment to the Passive Filterer FFG.

McShaffrey \& McCafferty (1988) argued about the importance of combining morphological and beha- 


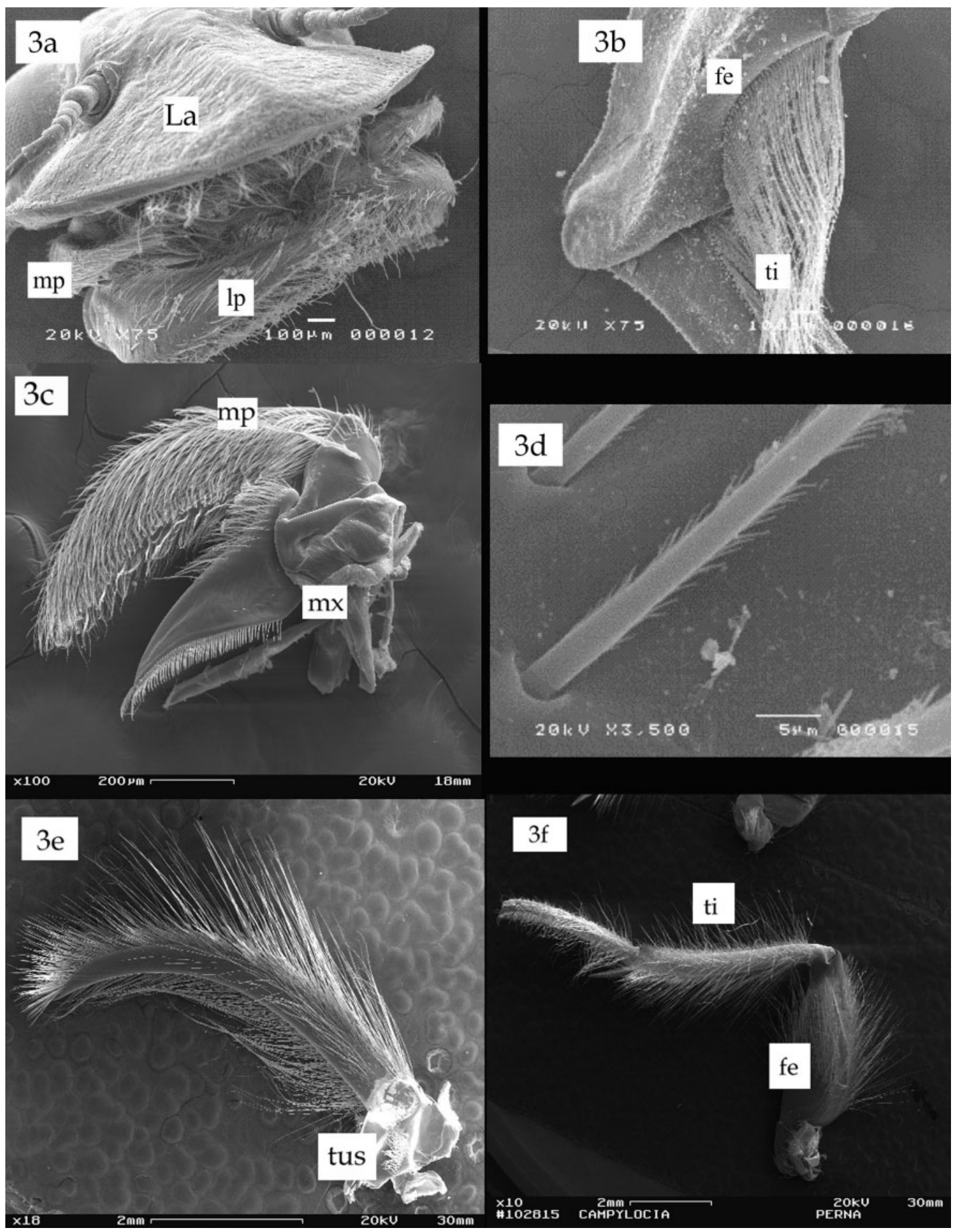

Fig. 3. Ultrastructure of mouthparts of Lachlania boanovae (Oligoneuriidae) and Campylocia sp. (Euthyplociidae) assigned to the Active Filterer FFG. (a) Frontal view of mouthparts of L. boanovae. La, Labrum; mp, Maxillary palp; lp, Labial palp. Scale bar 100 $\mu$ m. (b) Long setae of fore leg of L. boanovae. fe, Femur; ti, Tibia. Scale bar $100 \mu \mathrm{m}$. (c) Detail of maxilla of Campylocia sp. mx, Maxilla; mp, Maxillary palp. Scale bar $200 \mu \mathrm{m}$. (d) Detail of bipectinate setae in maxillae, maxillary palps and labrum of Campylocia sp. Scale bar $5 \mu \mathrm{m}$. (e) Detail of Mandible tusk (tus) of Campylocia sp. Scale bar $2 \mathrm{~mm}$. (f) Long setae of fore leg of Campylocia sp. fe, Femur; ti, Tibia. Scale bar $2 \mathrm{~mm}$. 


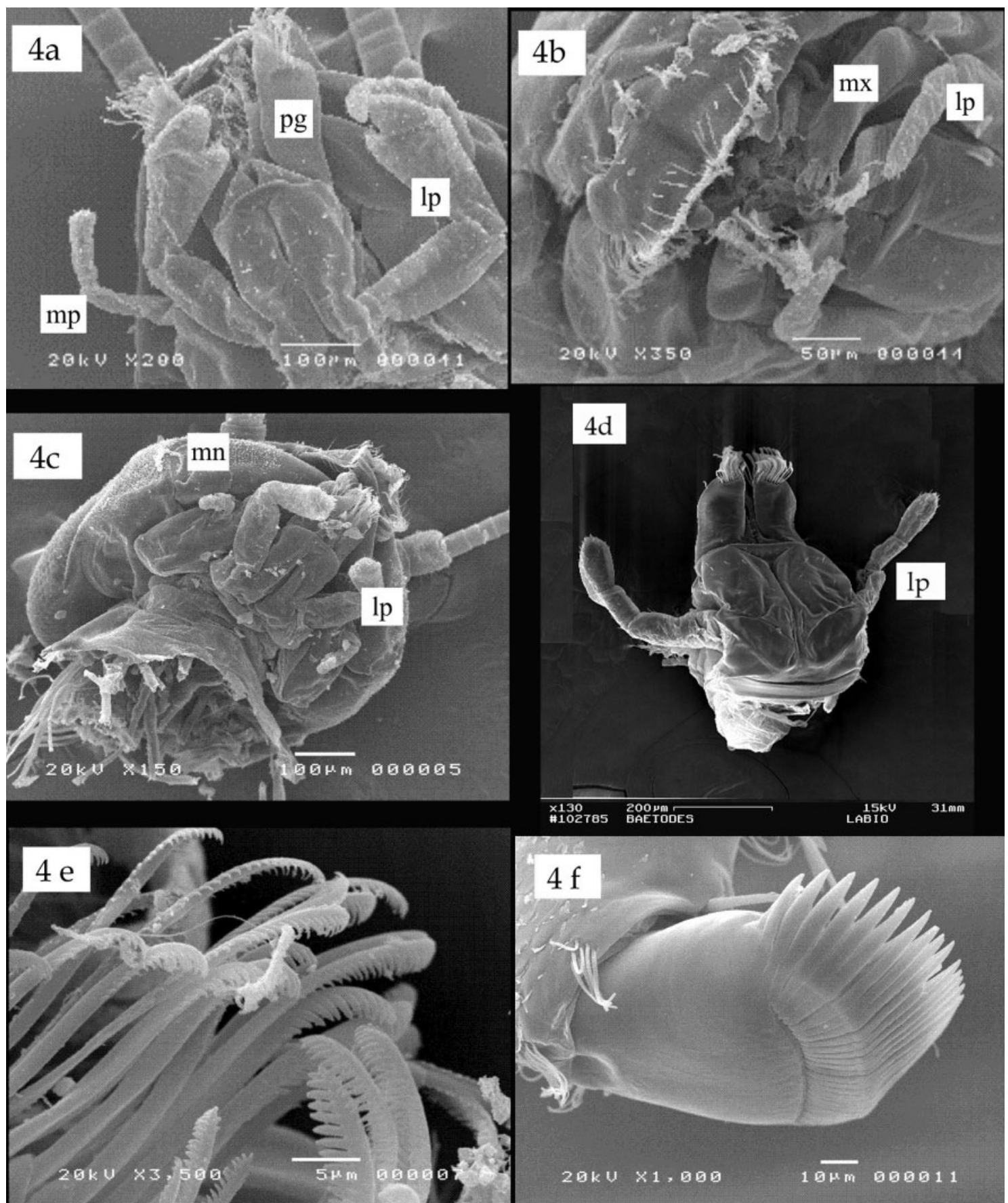

Fig. 4. Ultrastructure of mouthparts of Americabaetis spp., Baetodes sp. and Camelobaetidius spp. (Baetidae) assigned to the Collector-gatherer FFG. (a) Ventral view of mouthparts of Americabaetis spp. pg, Paraglossae; lp, Labial palp; mp, Maxillary palp. Scale bar 100 um. (b) Ventral view of mouthparts of Baetodes sp. mx, Maxillary palp; lp, Labial palp. Scale bar 50um. (c) Ventral view of mouthparts of Camelobaetidius sp. mn, Mandible; lp, Labial palp. Scale bar $100 \mu \mathrm{m}$. (d) Detail of labium of Baetodes sp. 1p, Labial palp. Scale bar $200 \mu \mathrm{m}$. (e) Detail of maxillary setae of Camelobaetidius spp. Scale bar $5 \mu \mathrm{m}$. (f) Tarsal claw of foreleg of Camelobaetidius spp. Scale bar $10 \mu \mathrm{m}$. 


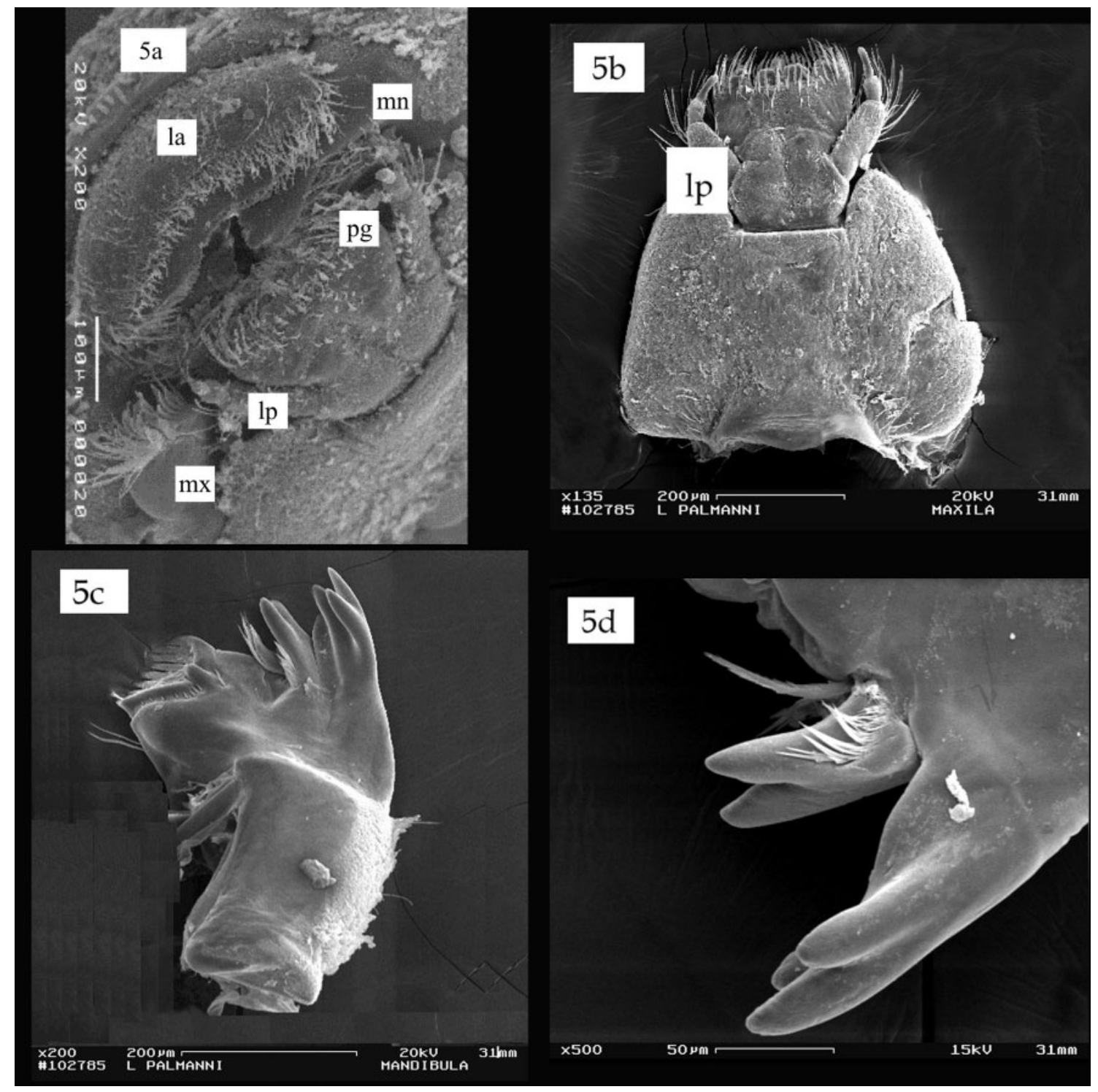

Fig. 5. Ultrastructure of mouthparts of Leptohyphes spp. (Leptohyphidae) assigned to the Scraper FFG. (a) Frontal view of mouthparts. La, Labrum; pg, Paraglossa; lp, Labial palp; mx, Maxillae; mp, Maxillary palp. Scale bar $100 \mu \mathrm{m}$. (b) Detail of Labium of Leptohyphes spp. lp, Labial palp. (c) Detail of distal part of mandible with two chitinous wedge-shaped teeth. Scale bar $200 \mu \mathrm{m}$. (d) Closer view of mandible with chitinous wedge-shaped teeth. Scale bar $50 \mu \mathrm{m}$.

vioural information for assignment to FFGs. In the present study, this was clear with Lachlania boanovae and Campylocia sp. which based simply on the ultrastructure of its mouthparts these species could be classified as Passive Filterer, but due to in-field observation of its behavior they were assigned to the Active Filterer FFG category. Also, the analysis of the prefer- red substrate was useful information for the assignment in FFGs categories in this study: both species were found predominantly in deposited litter substrates, indicating that they probably would not perform passive filtering as their predominant feeding cycle. Pereira $\&$ da Silva (1990) also found nymphs of Campylocia partially burrowed in soft sediments in pool areas in a 
high altitude stream reach (but not building and/or living in burrows like Ephemeridae - Merritt \& Cummins (1996)).

About the use of the terms Active or Passive Filterers, in terms of river function both groups are probably feeding on particles about the same size. However, Passive Filterers would contribute to organic particle retention in one stream reach while the Active Filterers (that would be assigned to the Collector-gatherer FFG in the Merritt \& Cummins (1996) classification scheme), when resuspending organic particle, would contribute to mobilization of these particles. Therefore, this information could be an indicative of organic matter cycling in streams.

The species of the family Baetidae are frequently assigned to the Collector-gatherer or Scraper FFG. According to Merritt \& Cummins (1996), Collector-gathererers feed on deposited decomposing organic matter, while Scrapers feed on periphyton-attached algae and associated material. Arens (1989) stated that head posture determines to a great extent the manner in which grazing insects can use their mouthparts to harvest algal pastures. In orthognathous Ephemeroptera, like baetids, only the tips of the mouthparts come into contact with the plain surfaces of the stones. Consequently, no mouthpart is especially suited to serve as a scraping organ because of its position.

In this study, based on mouthparts, all baetid species were assigned to the Collector-gatherer FFG category due to their complex buccal apparatus and long labial palps that may be used to gather and manipulate organic matter. This general morphologic plan is found in other neotropical baetid species (Lugo-Ortiz \& McCafferty 1996a, Lugo-Ortiz \& McCafferty 1997, Waltz $\&$ McCafferty 1999). Some Baetidae species found have specialized labial palp segment 2 with a moderate, distomedially acute process, highly adapted to manipulate food (Lugo-Ortiz \& McCafferty 1995, LugoOrtiz \& McCafferty 1996b; Dominique et al. 2000). Therefore, based on these characteristics baetids probably would be assigned to the collector-gatherers FFG, instead of scrapers FFG.

However, studies on exclusion of baetids conducted in south-east Brazil indicates that these species have a strong negative effect on the quantity of periphyton (Moulton et al. 2004), suggesting that these species are important herbivores in this region. Corroborating this, our baetid species occurred predominantly in stony substrates.

Villanueva \& Albariño (2003) studying the ingestion and digestion of one species of Baetidae and one spe- cies of Leptophlebiidae from a Patagonian Andean stream stated that since baetid nymphs had unspecialized mouthparts, the toothed-tips of both mandible and galea-lacinia acted as reaper more than as scraping devices. Once they found a high proportion of live periphyton cells ingested by the baetid nymph, and since the proportion of live algal cells is higher in the upper layer than in the inner zone, probably this species harvested only the upper layer of periphyton.

In accordance with these findings, species of Baetidae found in this study were assigned to the Grazer FFG, because they are able to use the tip of its mouthparts (similarly to the Collectors FFG as described by Arens 1989) however, to remove periphyton (same general food resource as the scrapers FFG, based on the resource partitioning idea of Cummins 1973).

In this study, species of Leptohyphidae were assigned to the Scraper FFG. The species Leptohyphes pereirae, Leptohyphes spp., Tricorythodes sp., Tricorythopsis sp. had mouthparts similar to those described in Palmer et al. (1993) as scrapers. According to Arens (1989), prognathous insects, like the leptohyphids in our study, press their mouthparts almost horizontally against the surface of the stones, so that larger areas of their labium and maxillae come into contact with algal pastures, therefore, prognathous insects should be able to graze down algal pastures more quickly than orthognathous species.

Scrapers are usually better at feeding on low-profile algae than those species with collector-gatherer mouthparts (Hill \& Knight 1988). Therefore, although grazers and scrapers feed on periphyton, these two groups are probably not feeding exactly on the same kinds of periphyton.

In summary, our study allowed some generalization related to the assignment of mayfly species to FFGs. Mouthparts morphology may limit its function for obtaining specific food resources. Based on general morphology of mouthparts, we speculate that species of Baetidae and Leptohyphidae studied probably can not perform brushing and filtering activities, since they lacked brushing and filtering setae. Leptophlebiid species studied (except for the passive-filterer Hylister plaumanni) had complex mouthparts with setae that would allow filtering and brushing activities and labial and maxillary palps that would allow gathering activities.

As a general pattern, species of the three best represented mayfly families in south-east Brazil could be assigned to different FFGs (Baetidae - Grazers; Leptophlebiidae - Brushers (except for $H$. plaumanni) and 
Leptohyphidae - Scrapers). This information could be useful because although it is important to identify organisms to the genus or species taxonomic level, it is always difficult to do so with neotropical fauna.

Our study also showed the importance of recording the substrate in which specimens were collected. This information could be used when determining the roles macroinvertebrates play in the stream, especially because behavioral information is difficult to collect and is often missing.

\section{Acknowledgments}

This work was partially funded by CNPq, FAPERJ and FIOCRUZ.

\section{References}

Arens W. 1989. - Comparative functional morphology of the mouthparts of stream animals feeding on epilithic algae. Arch. Hydrobiol./Suppl, 83, 253-354.

Arens W. 1990. - Wear and tear of mouthparts: a critical problem in stream animals on epilithic algae. Can. J. Zool., 68, 1897-1914.

Baptista D.F., Dorvillé L.F.M., Buss D.F. \& Nessimian J.L. 2001. Spatial and temporal organization of aquatic insects assemblages in the longitudinal gradient of a tropical river. Braz. J. Biol., 61, 295-304.

Bello C.L. \& Cabrera M.I. 2001. - Alimentación ninfal de Leptophlebiidae (Insecta: Ephemeroptera) en el Caño Paso del Diablo, Venezuela. Rev. Biol. Trop., 49, 999-1003.

Brown D.S. 1961. - The morphology and function of the mouthparts of Cloeon dipterum L. and Baetis rhodani (Pictet) (Insecta, Ephemeroptera). Proc. Zool. Soc. Lond., 136, 147-176.

Cummins K.W. 1973. - Trophic relations of aquatic insects. Annu. Rev. Entomol., 1, 183-206.

Cummins K.W. 1974. - Stucture and function of stream ecosystem. Bioscience, 2, 631-641.

Cummins K.W., Merritt R.W. \& Andrade P.C.N. 2005. - The use of invertebrate functional groups to characterize ecosystem attributes in selected streams and rivers in South Brazil. Stud. Neotrop. Fauna Environ., 40, 69-89.

Domínguez E. \& Flowers R.W. 1989. - A revision of Hermanella and related genera (Ephemeroptera: Leptophlebiidae: Atalophlebiinae) from subtropical South America. Ann. Entomol. Soc. Am., 82, 55-573.

Dominique Y., Thomas A., Orth K. \& Dauta C. 2000. - Les Ephémères de la Guyane Française. 2. Camelobaetidus billi et $C$. janae n. spp. [Ephemeroptera, Baetidae]. Ephemera, 2, 39-48.

Edmunds G.F., Jensen S.L. \& Berner L. 1976. - The Mayflies of North and Central America. University of Minnesota Press, Minneapolis, $330 \mathrm{p}$.

Elpers C. \& Tomka I. 1994. - Structure of mouthparts and feeding habits of Potamanthus luteus (Linné) (Ephemeroptera: Potamanthidae). Arch. Hydrobiol., 99, 73-96.

Froehlich C.G. 1964. - The feeding apparatus of the nymph of $A r$ - throplea cogener Bengtsson (Ephemeroptera). Opuscula Entomol., 29, 188-208.

Hill W.R. \& Knight A.W. 1988. - Concurrent grazing effects of two stream insects on periphyton. Limnol. Oceanog., 33, 15-26.

Lugo-Ortiz C.R. \& McCafferty W.P. 1995. - Three distinctive new genera of Baetidae (Insecta, Ephemeroptera) from South America. Ann. Limnol., 31, 233-243.

Lugo-Ortiz C.R. \& McCafferty W.P. 1996a - Aturbina georgei gen. et sp. n.: a small minnow mayfly (Ephemeroptera: Baetidae) without turbinated eyes. Aquat. Insects, 18, 175-183.

Lugo-Ortiz C.R. \& McCafferty W.P. 1996b - Taxonomy of neotropical genus Americabaetis, new status (Insecta: Ephemeroptera: Baetidae). Stud. Neotrop. Fauna Environ., 31, 156-169.

Lugo-Ortiz C.R. \& McCafferty W.P. 1997. - First report and new species of the genus Apobaetis (Ephemeroptera: Baetidae) from South America. Aquat. Insects, 19, 243-246.

McShaffrey D. 1988. - Behaviour, functional morphology, and ecology related to feeding in aquatic insects with particular reference to Stenacron interpunctatum, Rithrogena pellucida (Ephemeroptera: Heptageniidae), and Ephemerella needhami (Ephemeroptera: Ephemerellidae). PhD dissertation, Purdue University. [On line] Available: http://www.marietta.edu/ mcshaffd/phd/funcmore.html. Accessed on dec, 08, 2003.

McShaffrey D. \& McCafferty W.P. 1986. - Feeding behavior of Stenacron interpunctatum (Ephemeroptera: Heptageniidae). J. N. Am. Benthol. Soc., 5, 200-210.

McShaffrey D. \& McCafferty W.P. 1988. - Feeding behavior of Rithrogena pellucida (Ephemeroptera: Heptageniidae). J. N. Am. Benthol. Soc., 7, 87-99.

Merritt R.W. \& Cummins K.W. 1996. - An Introduction to the Aquatic Insects of North America. $3^{\text {rd }}$ ed. Kendall/Hunt Publishing, Dubuque, $862 \mathrm{p}$.

Moulton T. P., Souza M.L.., Silveira R.M.L. \& Krsulovic F.A.M. 2004. - Effects of ephemeropterans and shrimps on periphyton and sediments in a coastal stream (Atlantic forest, Rio de Janeiro, Brazil). J. N. Am. Benthol. Soc., 23, 868-881.

Palmer C., O'Keeffe J. \& Palmer A. 1993. - Macroinvertebrate functional feeding groups in the middle and lower reaches of the Buffalo River, eastern Cape, South Africa. II. Functional morphology and behaviour. Freshwater Biol., 29, 455-462.

Pereira S.M. \& da Silva E.R. 1990.- Nova espécie de Campylocia Needham \& Murphy, 1924 com notas biológicas (Ephemeroptera, Euthyplociidae). B. Museu Nacional Zool. Rio de Janeiro., 336, $1-12$.

Polegatto C.M \& Froehlich C.G. 2001. - Functional morphology of the feeding apparatus of the nymph of Farrodes sp. (Ephemeroptera: Leptophlebiidae). Acta Zool., 82, 165-175.

Vannote R.L., Minshall G.W., Cummins K.W., Sedell J.R. \& Cushing C.E. 1980. - The river continuum concept. Can. J. Fish. Aquat. Sci., 37,130-137.

Villanueva V.D. \& Albariño R. 2003. - Algal ingestion and digestion by two ephemeropteran larvae from a Patagonian Andean stream. Pages 468-475 in Research update on Ephemeroptera \& Plecoptera. Gaino E. (ed). Università di Perugia.

Waltz R.D. \& McCafferty W.P. 1999. - Additions to the taxonomy of Americabaetis (Ephemeroptera: Baetidae): A lugoi, n sp., adult of A robacki, and key to larvae. Entomological News, 110, 39-44. 